\title{
TEOLOGIA E CIÊNCIAS DAS RELIGIÕES: POR UMA OPOSIÇÃO EM PERSPECTIVA
}

\author{
Theology and Sciences of the Religions: For an opposition in \\ perspective
}

Pierre Gisel *

RESUMO: O texto retoma e aprofunda a relação entre teologia e ciências das religiões na atualidade, tendo como ponto de partida a situação europeia, e mais especificamente a Suíça, onde o autor, teólogo reformado, ensina. Começa com uma releitura da história dessas disciplinas na academia, na qual são apresentadas as dificuldades de cada uma: as ciências das religiões, provenientes da história das religiões e com falta de clareza quanto a seu método e a seu objeto, e a teologia, sobretudo a moderna, também com problemas de método e de objeto, já que somente suas disciplinas históricas são consideradas universitárias e não as sistemáticas. Após essa releitura, passa-se a uma interrogação mais aprofundada sobre o que diferencia as duas disciplinas nas sociedades pluralistas atuais, propondo, numa última parte, algumas modificações em ambas para uma fecundação mútua num mundo onde o campo religioso parece demandar uma inteligência mais apurada, que não pode ser dada apenas por uma abordagem das ciências das religiões e tampouco pela teologia.

Palavras-chave: Teologia, Ciências das Religiões, Pluralidade, Fato Religioso, Modernidade.

ABSTRACT: The text reexamines and deepens the relation between theology and sciences of the religions in the present time, having as starting point the European situation, and more specifically Switzerland, where the author, a reformed theologian, teaches. It starts with a rereading of the history of these disciplines in the academic sphere, in which the difficulties of each one are presented: sciences of the religions, proceeding from history of the religions and with a lack of clarity

\footnotetext{
* Faculdade de Teologia e de Ciências das Religiões da Universidade de Lausanne (Suíça). Artigo recebido no dia 02/08/2011. Autor convidado.
} 
in terms of its method and its object, and theology, overall modern theology, also with object and method problems, since its only historical disciplines are considered university and not systematic. After this rereading, the text advances with a deeper interrogation on what differentiates the two disciplines in the current pluralistic societies, proposing, in a last part, some modifications in both for a mutual enrichment in a world where the religious field seems to demand a more refined intelligence, that can be given neither by just a treatment of sciences of the religions and nor by just a treatment of theology.

KEYWORDS: Theology, Sciences of the Religions, Plurality, Religious Fact, Modernity.

\section{Em que situação nos encontramos? Uma primeira orientação}

$\mathrm{E}$ $\mathrm{m}$ nossos dias, a teologia e as ciências das religiões estão, numa perspectiva institucional, frequentemente em conflito ou mesmo nitidamente separadas. Isso é o reflexo de uma realidade mais ampla, social e cultural, de acordo com um contexto historicamente marcado - como sempre, em casos como este.

Evidentemente, esta situação não é a mesma no mundo inteiro. Ela é nítida na Europa: não somente na França laica - que pode ser considerada aqui um caso particularmente característico, sendo, portanto, inapropriado e mesmo perigoso tomá-lo como modelo ou como termo obrigatório e satisfatório de um processo histórico -, mas também no Reino Unido, nos Países Baixos, na Escandinávia e, cada vez mais, nos países de cultura germânica. A situação extraeuropeia é outra, e, além disso, diferenciada quando pensamos na América do Norte, na América Latina, na Ásia ou na África. Não se pode esquecer esta diversidade - ela relativiza e faz pensar -, porém nesta presente contribuição tomarei a Europa como ponto de partida. Caberá ao leitor verificar de que modo os dados aqui apresentados, assim como a maneira de relatá-los e tratá-los, podem ser esclarecedores, indiretamente ou de algum outro modo.

Quero fazer ainda uma pequena apresentação pessoal. Eu venho da teologia protestante, tendo sido marcado, quando estudante, pela "teologia dialética" (Karl Barth e Rudolf Bultmann). Progressivamente, entrei num trabalho crítico em relação às heranças que recebi ${ }^{1}$, indo além da focalização num kerygma no qual a transcendência ou a alteridade era central e no qual, relacionado a isso, a atenção à cultura, ao dado antropológico e a processos

${ }^{1}$ Minha tese sobre Ernst Käsemann, defendida em 1975, foi o primeiro passo dessa crítica. 
históricos diferenciados era fraca ou deixada fora do campo da reflexão teológica. Também se considerava pouco o jogo das mediações, das institucionalizações e, no que toca ao nosso tema, das ritualidades e dos símbolos. É nesse contexto que deve ser situada minha passagem pelo pensamento de Ernst Troeltsch (nos anos 1990), assim como uma forte frequentação e uma cumplicidade de fundo com o catolicismo (o que Tillich chamava de "substância católica", fazendo par, contraste ou oposição ao "princípio profético", princípio crítico e dito protestante). Também se situa neste contexto a retomada do que se sustentava por detrás do tema de uma "teologia natural", validada no catolicismo e declarada, por Barth, como sendo não "uma das numerosas heresias possíveis, mas a heresia por excelência"2. Deve-se a isso meu interesse pelo fato religioso e pelas religiões, mais amplos que o anúncio querigmático isolado ${ }^{3}$ um novo registro para a "teologia fundamental".

Parece-me conveniente acrescentar que eu me encontrei no centro de uma evolução institucional da Faculdade da qual sou atualmente Decano: ela passou de um estatuto de Faculdade de Teologia Protestante bastante clássico na Europa universitária contemporânea a um estatuto de Faculdade que integrou fortemente as Ciências das Religiões, outras ciências e uma perspectiva que se tornou, bem recentemente, a ponderação decisiva da Faculdade, não sem conflitos - diversos e reveladores ${ }^{4}$.

Quanto ao tema, parece-me - e isso vai comandar o que segue - que a oposição entre teologia e ciências das religiões deve ser não somente interpretada, como em todas as coisas, mas que ela deve ser descentrada. Isso supõe que se retrabalhem cada um dos dois polos em questão. E nós só poderemos fazê-lo se o conjunto for visto numa perspectiva histórica de larga envergadura e a partir de uma problemática também ampla. Assim se me apresenta uma problemática que toca as esferas do humano e do social, das quais o fato religioso e o dado teológico fazem parte; logo, estes últimos não são primeiros, nem tendo em conta o horizonte sobre o qual eles emergem e devem ser interrogados, nem quanto às questões que eles cristalizam ou assumem. E isso vale mesmo se, segundo uma perspectiva a ser validada, nós os consideramos decisivos ${ }^{5}$.

\footnotetext{
${ }^{2}$ Dogmatique, II/1* (1940), Genève: Labor et Fides, 1956, p. 140; cf. também o "Avantpropos" do conjunto, I/1* (1932), pp. XIs.

${ }^{3}$ Cf. meu livro Qu'est-ce qu'une religion?, Paris: Vrin, 2007 (trad. italiana a ser publicada no outono de 2011); precedentemente, a obra coletiva que eu dirigi com J.M. TÉTAZ, Théories de la religion: Diversité des pratiques de recherche, changements des contextes socio-culturels, requêtes réflexives, Genève: Labor et Fides, 2002.

${ }^{4}$ Sobre esta evolução e sobre o que ela apresenta de instrutivo, cf. meu livro Traiter du religieux à l'Université: Une dispute socialement révélatrice, Lausanne: Antipodes, 2011.

${ }^{5}$ Isso supõe retomar um trabalho sobre o que é a teologia; eu me esforcei para fazêlo em La théologie, Paris: PUF, 2007 (trad. italiana: La teologia: identità ecclesiale e
} 


\section{O que se entende geralmente por Ciência(s) das Religiões?}

Além de uma consideração dos registros da história, decisiva desde o século XIX e finalmente integrada no trabalho teológico - inclusive na maneira de considerar seus objetos e sua pertinência -, existem hoje diversas ciências humanas que se aplicaram no campo do fato religioso ou das religiões: a sociologia da religião (já era o caso de seus clássicos, Durkheim, Weber, Troeltsch, Simmel); a psicologia da religião (também já era o caso de seus clássicos, William James e, diferentemente, a psicologia das profundezas, Freud ou Jung); a antropologia cultural, nascida com a colonização extraeuropeia, que trabalha os sistemas simbólicos presentes numa cultura ou sociedade, as relações do humano com o diferente, consigo próprio, com o grupo, com o cosmos.

Desde a metade do século XIX, surgiu e se desenvolveu mais especificamente uma ciência ou uma história das religiões em diversas culturas europeias. Na Alemanha, sendo denominada Religionswissenschaft, ela foi integrada às Faculdades protestantes de teologia das Universidades frequentemente de um modo marginal, mas real, às vezes de um modo mais constitutivo -, nas quais se impôs, na virada dos séculos XIX e XX, uma religionswissenschafltiche Schule, com mais ou menos força segundo o lugar.

Notemos que, em nossos dias, o que pode constituir uma ciência das religiões como disciplina não é tão claro. A sociologia da religião é uma sociologia, aplicada, neste caso, às realidades do fato religioso; e se o trabalho neste campo puder modificar tal ponto interno à sociologia, a disciplina não ficará menos sociológica. Acontece o mesmo, mutatis mutandis, com as outras ciências humanas, como, por exemplo, a psicologia da religião, e igualmente a antropologia cultural, que trabalham, certamente, as disposições simbólicas de fundo que comandam a relação com o mundo, consigo próprias e com as alteridades, mas sem centrar-se no fato religioso como tal, o qual se encontra mesmo descentrado e restituído a disposições e a cartografias mais amplas. Porém, se se diz - ou quando se diz - ciência da religião, a incerteza é maior: o que dizer de seu método? E, relacionado a isto, o que dizer de seu objeto (um "objeto", neste caso, é construído e não equivale então a um "campo")?

pertinenza pubblica, Bologna: Dehoniane, 2009, ou romena: Theologia: Statutul, functia si pertinenta sa, Craiova: Editura Universitaria, 2007). Não sem relação, mas segundo registros próprios, deve-se retomar também, parece-me, o estado do ato de crer, por isso as obras coletivas: Les constellations $d u$ croire: Dispositifs hérités, problématisations, destin contemporain, Genève: Labor et Fides, 2009, e, dirigida com S. MARGEL, Le croire au cœur des sociétés et des cultures, Turnhout: Brepols (no prelo). 
Explicitemos isso um pouco mais. Comecemos pelo método: a ciência ou a história das religiões tem uma especificidade - metodológica - e, se tiver, qual é ela? Ou ela é primeiramente história, e então, provavelmente, uma história comparada? Ou se deve falar de ciências das religiões no plural, como se faz frequentemente? Mas, então, fala-se delas como ciências separadas ou como um feixe de disciplinas? Consequentemente, aparece a questão: o que organiza este feixe?

Quando se fala do objeto de uma ciência ou de uma história das religiões, a questão é ainda mais desagregadora (aliás, rigorosamente, é o que faz com que a questão do método escape ou se disperse): não somente as religiões constituídas são historicamente construídas (as ciências humanas e sociais contemporâneas não cessam de sublinhá-lo contra toda perspectiva denunciada por elas como "essencialista"), mas o que o próprio termo "religioso" pode designar é uma construção cultural: o que ele circunscreve não se encontra em todas as culturas ou em todas as civilizações, e quando ele designa um campo próprio - como na história ocidental permeada de cristianismo -, este campo é, de fato, um "cenário", no qual realidades antropológicas e sociais mais amplas vêm se apresentar.

Para além dos questionamentos que acabamos de levantar - e que permanecem -, convém, no entanto, considerar a constituição progressiva de uma ciência ou de uma história das religiões, pondo em evidência uma história dos problemas, de suas modificações num tempo determinado e dos debates ligados a eles ${ }^{6}$. Consequentemente, aparece assim um pano de fundo que constitui efetivamente uma ordem própria de interrogações e de problemáticas, uma ordem que se pode elucidar.

Em relação ao período contemporâneo - que pode ser inscrito como um momento próprio desta história da constituição de um campo de problemas diverso e mutante, mas segundo mudanças centralmente instrutivas -, convém provavelmente destacar uma modificação no coração das ciências humanas, uma passagem da história e da filologia - sobre as quais se apoiavam emblematicamente um Dilthey ${ }^{7}$, mas também Heidegger, a sua maneira, e Ricœur, em parte - a uma mobilização de ciências humanas como a semiologia, a pragmática, a análise do discurso, a história das

\footnotetext{
${ }^{6}$ Passa-se então pelo que cristalizam os nomes, por exemplo, de Max Müller, Jonathan Smith, James Frazer, Emile Durkheim, Max Weber, Marcel Mauss, Bronislaw Malinowski, Mircea Eliade, Raffaelle Pettazoni, Georges Dumézil, Ernesto di Martino, Arnaldo Momigliano, Jean-Pierre Vernant, Marcel Detienne, Talal Asad, Clifford Geertz, Mary Douglas, Jan Assmann e muitos outros.

${ }^{7}$ Cf. K. FLASCH, Prendre congé de Dilthey: Que serait un néohistorisme en histoire de la philosophie?, seguido de Congé à Dilthey, Paris: Belles Lettres, 2008; cf. também P. VEYNE, Foucault, sa pensée, sa personne, Paris: Albin Michel, 2008, ou C. GALLAGHER / S. GREENBLATT, Practicing New Historicism, Chicago: University of Chicago Press, 2001.
} 
mentalidades ou os cultural studies, articulados à antropologia e à história social. Em paralelo, emergem interrogações transversais que escapam aos confinamentos disciplinares herdados e aos objetos que os especificam e que são especificados por eles.

Neste caso, a interrogação repousa sobre as lógicas culturais e sociais, sempre historicamente marcadas, que perpassam os discursos, as práticas, as instituições ou todas as formas de produção cultural. Assim, as ordens e as relações de organizações institucionais e simbólicas vêm ao primeiro plano, reclamando e especificando momentos de inteligibilidade. Consequentemente, não há mais um fato religioso como objeto ou como campo definido desde sempre, cujas variedades e variações deveríamos estudar e compreender, mas construções contingentes de ordens do mundo, feitas de relações efetivas, concretas e simbólicas - sociais, evidentemente. Neste ponto, estamos marcados pela antropologia; e o que se pode desenvolver aí de uma abordagem histórica e comparativa repousa sobre relações - relações internas ao que faz o momento de uma cultura ou de uma civilização, em última instância sempre mestiça, e relações entre momentos diversos - mais do que sobre um objeto particular. Nada de "universais" aqui, filosóficos ou teológicos.

Em minha opinião, tal trabalho pode se concentrar na Modernidade e no que acontece conosco nesse período, inserindo-a numa perspectiva crítica e genealógico-comparativa de larga amplitude: passando notadamente pela Antiguidade tardia, contrastada com o que a precede, a Idade Média, o Renascimento, a Modernidade clássica e o período Contemporâneo. Isso colocará em evidência, por exemplo, uma história diferenciada do fato teológico-político, de suas variantes e dos jogos de dissidências articulados a ela, um dado genealógico-comparativo que está ele próprio em relação com outros períodos civilizacionais, de outros lugares, tecidos de outra maneira. Toda emergência de uma novidade, assim como toda evocação de um dado antigo - memória, referência ou período do qual se demarcar -, será o objeto de uma "historização" inscrevendo sua novidade numa duração prolongada, feita de rupturas heterogêneas e de redistribuições.

O que acabo de indicar como deslocamento no coração das ciências humanas, e o que nelas se pode mobilizar em matéria de religião - e a fortiori esta visão situando um presente segundo uma perspectiva genealógico-comparativa - não está sempre presente (longe disso!) nas ciências das religiões. Estas se contentam frequentemente em descrever, mesmo podendo se maravilhar com riquezas e com diversidades insuspeitas ou pôr em evidência o que é estranho. E isso com uma grande prudência - e mesmo com desconfiança - em relação a qualquer trabalho reflexivo sobre as questões e os problemas que estão em jogo.

Enfim, tocando um ponto contingente, mas muitas vezes determinante que, aliás, está por detrás da prudência que acabamos de evocar --, convém 
assinalar que a constituição progressiva de uma ciência ou de uma história das religiões fez-se majoritariamente segundo um processo de emancipação em relação à teologia. Consequentemente, as ciências das religiões podem às vezes reconhecer suas hesitações quanto ao que elas são, mas em compensação elas sabem muito bem o que não são: elas não são teológicas. Eis aqui um dado a ser retomado, examinando o que ele diz de pertinente - $\mathrm{e}$ em que consiste esta pertinência -, assim como o que nele provém do imaginário - e em que consiste este imaginário. Além disso, deveremos examinar o porquê de um fenômeno como esse.

\section{O que é a teologia?}

Se o que pode determinar uma disciplina chamada ciência das religiões não é muito claro quanto a método e objeto específicos - mas sim quanto ao apoio encontrado num campo diferenciado de problemáticas, constituído historicamente -, o que determina a teologia como disciplina não é, desde o surgimento do trabalho histórico (o essencial do campo de atividade dos teólogos), tampouco mais claro.

No começo do século XIX, no contexto protestante, Friedrich Schleiermacher havia proposto uma perspectiva repensada e reordenada ${ }^{8}$, para além e não aquém da Aufklärung - tendo integrado então seu momento -, mas ela ratifica justamente que, no plano dos métodos, o trabalho provém das diversas disciplinas mobilizadas: a especificidade da reflexão teológica não consistiria então num método, mas numa interrogação transversal. Os debates recorrentes entre exegese histórico-crítica e teologia sistemática (ou dogmática e fundamental) atestam que as coisas não foram sempre bem esclarecidas neste caso (e isso é o mínimo que podemos dizer ${ }^{9}$ ). No contexto católico, a história da controvérsia passa por Johann Sebastian Drey, que propunha na mesma época uma reorganização paralela à de Schleiermacher, mas com uma marca mais romântica e mais eclesiocêntrica (cf. sua Brève introduction à l'étude de la théologie, de $\left.1819^{10}\right)$, pela crise modernista (1907, pensando na condenação), pelo conflito entre a "nova teologia" e o neotomismo (por volta de 1937-1950).

\footnotetext{
${ }^{8}$ Cf. seu Kurze Darstellung des theologischen Studiums (1811 e 1830), trad. francesa: Le statut de la théologie: Bref exposé, Paris / Genève: Cerf / Labor et Fides, 1994. ${ }^{9}$ Cf., recentemente, os traços de divergência sobre a recepção da obra de J.P. MEIER (A Marginal Jew; trad. francesa: Un certain Juif Jésus), in "Christologie et histoire de Jésus. II: Faire aujourd'hui une théologie de la vie de Jésus?", Recherches de science religieuse 99 (2011/n.1) (notadamente o artigo de Joseph Moingt).

${ }^{10}$ Cf. J.S. DREY, "Brève introduction à l'étude de la théologie", in M. SECKLER (org.), Aux origines de l'école catholique de Tübingen, Avec des contributions du Cardinal Joseph Ratzinger, du Cardinal Walter Kasper, et de Max Seckler, Paris: Cerf, 2007, pp. 161-389.
} 
Como os dados são pouco claros, ratifica-se às vezes, sem descentramento nem crítica, reflexos espontâneos da cultura do tempo nas crises institucionais intrauniversitárias que afetam a teologia. Assim, entre os teólogos, alguns se dizem prontos a admitir, num movimento de recuo, que somente as disciplinas históricas, incluindo a exegese histórico-crítica da Bíblia, são universitárias, e não a teologia sistemática (ou dogmática e fundamental), reputada como "especulativa", a qual poderia somente, no fim das contas, debruçar-se sobre um exercício que pertence ao domínio da eclesialidade e da fé, a exemplo da teologia prática ou pastoral.

Ora, fazendo isso, ratifica-se então, a meu ver, uma inclinação sociocultural contemporânea global - pós-moderna? - que quer que não haja nada de pensável nem de argumentável entre, de um lado, saberes objetivos, no fundo concebidos de um modo bastante positivista ou mesmo tecnocrata (ou saberes tão especializados que são ocupados pelo que se chamava há algumas décadas "Fachidioten") e, do outro lado, puros julgamentos de valor subjetivos e privados e, neste sentido, arbitrários. Há de se temer, aqui, acima de tudo, e com toda a razão, cair na intolerância ou no imperialismo.

Então, mais especificamente relacionado ao nosso tema, ratifica-se que as ciências das religiões são disciplinas universitárias (a parte histórica do que se trabalha hoje em teologia podendo juntar-se a elas), e que a teologia não o é, ou não inteiramente: uma parte deveria então emigrar para fora da academia, mas, além disso, para fora de um campo de pertinência social e também de argumentação pública. Diante do que foi o exercício teológico em nossa história, eis o sinal de um colapso intelectual nocivo a todos e, no que toca ao cristianismo, uma "sectarização" de fato.

Este contexto exige globalmente, no plano remoto, por um lado, retrabalhar, problematizar e reconstruir o que se entende por saberes: o que significam problemáticas objetiváveis, ou mesmo tipologizações e organizações comparativas, incorporadas a desafios que concernem ao humano e aos desdobramentos - individuais e coletivos - de sua existência? E, por outro lado, é necessário retrabalhar o que se esconde muitas vezes nas palavras convicção ou identidade assumida: o que podemos dizer do crer, distinto notadamente do saber - e de outras instâncias perpassando o humano igualmente -, do que sustenta sua existência e seus desdobramentos inclusive as patologias -, do que constitui sua própria postura, historicamente marcada?

Em debate ou no face a face com as ciências das religiões, convém concretamente retrabalhar o que faz ou não a objetividade, reivindicada e podendo ser em princípio assegurada (ao menos parcialmente), e a confessionalidade, declarada a partir de uma convicção ou rejeitada a partir de uma posição pessoal crítica. E convém retomá-lo aprofundando e problematizando o que se condensa em cada um dos dois polos em questão. 
Além desta retomada descentralizadora de determinadas divisões e cristalizações (a ser feita num horizonte sociocultural amplo), deve-se retomar especificamente o que é, pode ser ou deve ser o teológico, vinculado ao que ele foi historicamente, descentrando aí também uma situação contemporânea que tende a se tornar dominante, em uns como em outros, nos adversários da teologia como em seus defensores.

\section{Uma interrogação para além da consideração da diversidade religiosa}

Em nossos dias, o surgimento de uma ciência ou uma história das religiões não põe em evidência somente uma pluralidade de religiões ou de formas do fato religioso, descentralizando o cristianismo e submetendo-o à comparação - o que não é pouco e pode levar longe. Neste fato, mostra-se igualmente que as categorias que são espontaneamente as nossas, longe de serem naturais, são construídas e, longe de serem universais, são particulares.

Concretamente, a ciência ou a história das religiões põe em evidência que estas categorias são, fora de toda questão de fé ou de neutralidade axiológica, construídas no solo do cristianismo. Sobre este ponto, o descentramento em curso não equivale a simplesmente constatar uma pluralidade e a dar, desde então, um lugar a uma pluriconfessionalidade, segundo um modelo que podemos constatar particularmente na América do Norte, não sem relação, provavelmente, com uma tendência social comunitarista.

Dois exemplos, por sinal frequentemente postos em destaque nestes debates, ilustram esta não-neutralidade das categorias com as quais geralmente trabalhamos: o crer (ou a decisão de existência, o engajamento pessoal, o controle sobre si, no íntimo e em radicalidade de vida) e Deus (ou o absoluto, o último, o incondicionado).

Os historiadores das religiões lembram ou põem em evidência que o crer não se encontra em todo lugar, nem em todos os tempos. Assim, religiões précristãs antigas, por exemplo (cf. Jean-Pierre Vernant, Marcel Detienne, Philippe Borgeaud, John Scheid), nas quais o que nós chamamos religião é, antes de tudo, um rito a cumprir, ligado a um equilíbrio cósmico - e a realizar por quem quer que seja e de onde quer que venha -, ou uma ratificação dada a uma pertença civil, ligada à organização concreta. Ainda outro exemplo, proveniente de um modo completamente diferente, o das espiritualidades contemporâneas pós-cristãs podendo ir até apresentaremse como ateias ${ }^{11}$, mais ligadas ao equilíbrio ou à higiene de vida do que ao

${ }^{11}$ Por exemplo, A. COMPTE-SPONVILLE, L'esprit de l'athéisme: Introduction à une spiritualité sans Dieu, Paris: A. Michel, 2006.

Perspectiva Teológica, Belo Horizonte, Ano 43, Número 120, p. 165-192, Mai/Ago 2011 
que se chama ou se chamava "fé" no cristianismo. Além disso, muitos judeus intransigentes (um Yeshayahou Leibowitz, por exemplo, faz isto nitidamente) sustentam igualmente que aquilo que o cristianismo entende por crer não existe no judaísmo: nele cumpre-se a Lei, a partir de ritos objetivos e exteriores, fora de uma problemática de autenticidade ou não, fora desta dramática da alma, própria à religião cristã, que aproximou demais Deus do homem, enquanto que só o arbitrário da Lei, apenas, assegurava sua transcendência, que é inapreensível. No inominável da perseguição, um judeu ateu pode cumprir o rito e, de todo modo, um judeu ateu permanece judeu.

Acontece o mesmo com Deus (o absoluto, o último, o incondicionado, e sua ausência também): a temática não se encontra, com efeito, em todo lugar nem em todos os tempos, e esta categoria, mesmo secularizada ou transposta (os absolutos das ideologias ateias - secularismos, como se disse, os marxismos tendo despertado muitas reflexões sobre este assunto, não isentas de pertinência), não pode legitimamente ou pertinentemente ser mobilizada para trabalhar toda manifestação do que podemos chamar religião ou fato religioso.

A meu ver, esconde-se particularmente neste último ponto uma ilusão dos teólogos. Eles aprenderam (da "teologia dialética" e de Paul Tillich especialmente) que ideologias podiam funcionar como religião - a modernidade dos séculos XIX e XX tendo posto isso nitidamente em evidência - e que o homem podia habitar este campo e suas modalidades de desdobramento numa "denegação do religioso". Ora, o que era pertinente naquele contexto não o é no campo mais amplo das religiões extraeuropeias, ou religiões marginalizadas, esotéricas ou étnicas ${ }^{12}$.

Considerando tudo isso, a ciência ou a história das religiões inicia uma reflexão não somente sobre os diferentes modos de preencher os mesmos compartimentos (os da transcendência, da ritualidade, das mediações, etc.), mas sobre a própria balizagem do terreno ou do espaço sobre o qual tínhamos disposto compartimentos diversos, diferentemente ocupados. Encontramonos aí além de toda comparação de termos, realizada num horizonte indevidamente homogeneizado, sendo necessárias visões civilizacionais mais amplas, tanto sincrônica quanto diacronicamente (inclusive de outros lugares, a meu ver), no tocante às trajetórias ditas cristãs ou reivindicadas como tais. Isso não é dado espontaneamente à consciência crente, nem sempre acordado por críticos do cristianismo demasiadamente implicados a denunciá-lo globalmente, consequentemente não sem cegueira sobre si.

\footnotetext{
${ }^{12}$ Cf. meu artigo "De Bultmann à aujourd'hui. Ou d'un déplacement quant à la question de Dieu", in G. VAHANIAN (org.), Les lunettes de Dieu: Bultmann et l'invention de la foi, Foi et Vie (2010/n.1) 89-103.
} 
Destaquemos outro aspecto que deve ser bem percebido em relação ao que estamos questionando aqui. Se as categorias intelectuais são construídas no solo do cristianismo e estão ligadas a ele, para além de qualquer questão de fé ou de engajamento crente, isso significa que estas categorias são as de um universo cultural determinado e não próprias ao cristianismo como tradição - não são determinadas "bens da salvação". Ora, isso não é válido somente porque nós estamos numa era pós-cristã (marcados então por uma herança precisa), mas também para o período no qual se constituiu o cristianismo, num terreno comum de interrogações e de problemáticas que não eram como tais ligadas ao que ele sustentava ou teria podido sustentar por si próprio, mas que o ultrapassava. Assim, este é justamente o caso da centralidade das questões tanto de Deus (de uma transcendência além das religiões cívicas e familiares) quanto do crer (de um itinerário da alma além da estrita ritualidade ou da pertença particular a uma cidade), onde no centro da Antiguidade tardia, o cristianismo, as gnoses, o maniqueísmo e o neoplatonismo são concorrentes simplesmente porque são, antes, cúmplices.

No cristianismo - e no próprio período de sua constituição como religião - o que comanda suas interrogações, as formas de sua sistematicidade teológica assim como o teor de seus elementos (uma salvação vinda do alto, com o jogo de suas dialéticas possíveis com o corpo, a matéria e as instituições), sua articulação ao espaço do mundo, ligada a um progresso do polo representado pela alma individual, sua temática diferenciada e central da ou das mediações, em relação com uma reflexão aprofundada sobre a compreensão do que se deve entender por princípio, o tipo de seus desdobramentos: tudo isso provém de uma disposição, de um campo de problemas e de questões explícitas que são as da época. Explicado de outro modo: o que os sustenta e lhes dá forma não vem da Bíblia. Uma história cultural do cristianismo, do tipo que pode abrir ou fecundar uma ciência ou uma história das religiões, põe-no seguramente em evidência.

\section{Ultrapassar a oposição estrita: por quais modificações ou quais aprofundamentos?}

Ultrapassar, de uma maneira frutuosa para cada uma, a pura oposição - ou a separação pacificadora - entre ciências das religiões e teologia supõe entrar no tipo de deslocamento indicado por nós, para além de qualquer comparação termo a termo de asserções diferentes, qualquer declaração ou não de adesão ou de crença, qualquer divisão entre neutralidade e engajamento, qualquer declaração de conviç̧ão: com efeito, uma convicção se constrói, o que supõe um espaço próprio de desafios aos quais se pode responder e aos quais se responde efetivamente. 
Isso conduz a diversas modificações ou a alguns aprofundamentos, tanto do lado da teologia quanto do lado das ciências das religiões.

\section{a) Modificações e aprofundamentos no campo da teologia}

No campo da teologia, convém primeiramente, a meu ver, ingressar diretamente no terreno ocupado e trabalhado pela história e pelas ciências das religiões. Não se trata imediatamente da mesma tarefa de acompanhar ou de alimentar os fiéis e suas comunidades - ainda que estas duas tarefas possam ser realizadas em paralelo e influenciar uma a outra -, mas é uma tarefa necessária e mesmo indispensável. A meu ver, numa época "pós-metafísica", este é o lugar (com as modalidades a ele ligadas) que deve ocupar hoje o que se chama no catolicismo, desde o século XX, "teologia fundamental".

Em seguida, no que diz respeito mais especificamente às formas que fazem ou que fizeram o cristianismo - sua ritualidade, seu sistema simbólico e sacramental, seus enunciados de doutrina, etc., portanto, no interior -, convém fazer um trabalho que mostre e pense cada um dos elementos que estão em jogo como uma maneira de responder a questões humanas mais amplas. Eis aí um desafio, intrínseco ao exercício teológico tal qual ele foi pensado e assumido no cristianismo, ao longo do tempo, mas que pode ser perdido de vista, em parte ou até mais, numa época moderna na qual tende a imporse a temática de uma revelação compreendida como momento inaugural que autoriza ou legitima -, apreendida, além disso, como espaço ou conjunto de bens próprios e específicos, escriturais e/ou eclesiais. Que este momento seja recebido como momento aberto, num horizonte amplo e tendo por finalidade o mundo de todos, ou que ele seja vivido como momento concernindo primeiramente à edificação de uma comunidade mais ou menos separada do mundo e destinada a uma escatologia futura, isso não muda em nada o discurso. Com efeito, o que está em questão é saber se se parte do mundo e do humano, para realizar, a partir do interior e no interior, sua retomada específica - responder a partir do que eles são - ou se se parte de uma situação extrínseca, mesmo querendo atingir este mundo e este humano. A articulação entre transcendência e imanência, cristianismo e realidade mundana, confissão e humanidade não acontece da mesma maneira num caso ou no outro.

O leitor terá compreendido que, a meu ver, não seguir a exigência aqui tratada leva a uma "sectarização", ou a atesta - tanto na relação com a sociedade como na relação com a verdade, duas coisas, de fato, sempre ligadas -, uma "sectarização" nem sempre percebida, podendo ser soft (havendo também as hard). Além disso, o leitor terá compreendido também que, no duplo ponto indicado (a escolha do terreno e a maneira de trabalhar no interior as realidades do dispositivo cristão), a interface - e, consequentemente, a interação - com a história ou as ciências das religiões 
não desqualifica nem substitui os dados tratados pela teologia, mas os descentra, iniciando ou alimentando uma problematização - e isso ela o faz para além das divisões habituais.

\section{b) Uma ampliação no campo das ciências das religiões}

No campo das ciências das religiões, convém primeiramente, a meu ver, não se satisfazer com uma postura visando a mostrar a diversidade e a se alegrar dos efeitos de estranheza que podem resultar daí, nem tampouco se satisfazer com uma postura visando a instruir uma crítica do religioso herdado - cristão ou, além disso, monoteísta -, mesmo se estes dois momentos são legítimos e necessários. Deve-se certamente conhecer - e estender seus conhecimentos - e isto não será sem proveito humano e social; do mesmo modo que deve sempre, e sempre de novo, submeter à crítica as próprias heranças recebidas. Todavia, deve-se também pensar, e neste ponto, as ciências das religiões estão frequentemente, a meu ver - nem sempre, nem em todo lugar -, a um passo atrás. Por dificuldade intrínseca? Por reserva ou por causa de diversos fenômenos de disseminação devidos a nossa época? Por um temor, secreto ou explícito e assumido, de cair na teologia, ou ao menos de não estar isento de normatividade e de etnocentrismo? É um pouco de tudo isso.

Em seguida, ainda no campo das ciências das religiões, convém tratar o cenário religioso, histórica e socioculturalmente construído, como um cenário sintomático de realidades sociais e antropológicas, e um cenário a partir do qual se desenvolvem efeitos, igualmente antropológicos e sociais. O fato de que uma situação seja tida como construída - e nestas matérias, toda realidade social é construída, a política entre outras - não significa que ela não "exista". Do mesmo modo, o fato de ela ser reconhecida como contingente - e assim "arbitrária", como se gosta de sublinhar - não quer dizer que ela seja sem significações e sem desafios. Em minha opinião, convém estabelecer, especialmente nestas matérias, uma genealogia de nossa história - cristã e monoteísta - e do que nós recebemos dela hoje: do que dela se transpõe, se recompõe e sai de órbita. Uma genealogia do que nós recebemos desta história, humanamente e socialmente.

Neste tipo de trabalho, pessoas que, provenientes da teologia, tenham integrado as transformações notadas no primeiro ponto desta seção, e pessoas que, provenientes das ciências das religiões, tenham integrado as dimensões que acabamos de indicar, podem e deveriam trabalhar juntas. Como evocado, trata-se de um trabalho que abre a um pensar, renovado e assumido como tal, para além dos conhecimentos descritivos isolados, quer internos a uma tradição, a uma proveniência ou a uma herança, quer diferentes, mais exóticos, desconhecidos e esquecidos, ou mesmo recalcados.

Eu indiquei a que os teólogos são convidados - as Igrejas também, e pela mesma razão. Parece-me que há neste lugar de combate, ao menos na Eu- 
ropa, como uma pane. Não somente os teólogos têm dificuldade de dar crédito à perspectiva aqui aberta - que supõe certamente um trabalho intelectual sério e inventivo, como deveria ser todo trabalho intelectual -, mas eles parecem tomados pela tarefa de redizer uma identidade, e de redizê-la ao interior. Provavelmente, eles se sentem solicitados a esta tarefa por um cristianismo que se encontra muito abalado. Ao mesmo tempo, este trabalho tornou-se plausível graças a uma sociedade pós-moderna que não sabe muito bem como pensar a sociedade como tal (o "bem comum"), deixando, consequentemente, o campo livre ao posicionamento de atores diversos que devem demonstrar suas capacidades.

Entretanto, reciprocamente ao trabalho indicado, o leitor terá compreendido que se deve validar e tornar operacional no terreno das ciências das religiões uma parte das questões historicamente sustentadas pela teologia em nossa história, questões por nós certamente transformadas segundo o que é exigido agora. Do mesmo modo, questões sustentadas pelo trabalho teológico podem e devem ser assumidas no campo examinado pela filosofia, ou ainda em outras disciplinas. Lembremo-nos que, de todo modo, as distinções de campos disciplinares - aqui a teologia, a filosofia e as ciências das religiões - têm uma história, como toda repartição deste gênero. Devese, além disso, não somente manter ou fazer emergir interrogações transversais, mas ajudar as reconfigurações dos campos. Aliás, nós vivemos numa época na qual isto está especialmente em jogo, pelo menos e mais significativamente, nestes três campos. Ora, se os teólogos tendem a se fechar sobre o que seria o "bem próprio"13 , do lado das ciências das religiões - além da desconfiança, e mesmo das caricaturas ou simplesmente do desejo de romper com uma vizinhança para realizar algo realmente novo -, a perspectiva de retomar em seu terreno, mesmo mutatis mutandis, uma parte do que sustentava o trabalho teológico e do que era sustentado por ele em nossa história é, salvo exceções, socioculturalmente pouco audível.

\section{Ensaio ilustrativo: o fato religioso na cidade hoje, política e civil}

Nesta última parte, desejo propor uma aplicação prática, para não me deter numa descrição um pouco formal e teórica nem num esboço programático do que seria desejável.

Escolhi retomar a situação atual de nossa modernidade, na perspectiva aberta no ponto precedente. Em que ponto estamos? Esta questão compreen-

${ }^{13}$ Sobre o terreno preciso que foi o meu nestes últimos anos, eu mostrei um funcionamento em curso, em Traiter du religieux à l'Université. 
de outras: "De onde viemos?", “O que recebemos desta proveniência?" e também "O que acontece a esta proveniência?". Ora, esta proveniência era, ao mesmo tempo, cristã e feita de contestação ou rejeição do cristianismo ou, mesmo para além dele, do fato religioso. As ciências das religiões se consagram a isso sob o modo da rejeição, de maneira diversa e variável, mas principalmente em relação ao cristianismo e à teologia que supostamente o defendia (estando de todo modo ligada a ele, quer ela seja confessante ou não). Concluímos o que precede evocando que, para além da rejeição das respostas - que se percebe na maioria dos casos -, a rejeição do teológico não dizia respeito somente a uma determinação do questionamento, mas também e num mesmo movimento, significava a rejeição ou a obstrução do que o sustentava, podendo haver uma perda neste ponto: uma dificuldade para lidar com o conjunto de questões subjacentes ao contemporâneo e uma leitura truncada do que fez e faz nossa história e nosso presente.

A ilustração que segue vale como um desdobramento de problemáticas que devem ser contempladas quando se trata do religioso - às quais a teologia e as ciências das religiões são então convocadas. Entretanto, elas não poderão realmente assumir e esclarecer estas problemáticas sem modificar, no sentido que até agora conseguimos esboçar, o seu modo de abordar ou de deixar de lado e intacto tal aspecto.

\section{a) $O$ que podemos dizer de nosso presente?}

Começo retraçando a paisagem de nossas sociedades ocidentais contemporâneas em matéria de fenômeno religioso: este é nosso pano de fundo. Eu o farei sem me contentar em listar grupos precisos, mas delimitarei também as formas tomadas por eles e assinalarei ainda o posicionamento social adotado cada vez por seus atores. Com efeito, são estes diversos traços que podem colocar em evidência se se encontra em ação - e em quê - uma disposição sociocultural de conjunto, o que deve ser aqui meu interesse primeiro, como o leitor terá compreendido.

Noto, primeiramente, a preservação de tradições e de instituições antigas as Igrejas cristãs particularmente -, mas afetadas por modificações bem fortes em seu interior. Às vezes, uma adaptação fraca, não sem secularização de diversas ordens, mas também com reafirmações identitárias mais visíveis de tipo confessante e mesmo integrista ou fundamentalista. Isso é acompanhado por um posicionamento comandado não pela antiga noção de "bem comum" (o que permite a cada um e a cada organização sua perfeição própria, num clima de diferenças ratificadas como irredutíveis, logo legítimas e, ao menos indiretamente, potencialmente fecundas), mas por uma auto-afirmação - seja ela pensada como ideal ou como benéfica para todos - no mercado competitivo de crenças justapostas ou de partidos diversos. Aqui, prima a questão da identidade, e ela é pensada como específica. 
Registro, em seguida, o que os sociólogos denominam "novos movimentos religiosos", como a Cientologia, a Ordem do Templo Solar, os Raelianos. São grupos com fronteiras nítidas e com uma organização interna forte. Criações modernas, mais precisamente contemporâneas, quanto ao fato, mas também quanto aos seus traços (propensão a sobrepor saber e crer, referência a forças supranaturais mas não heterogêneas, empréstimos múltiplos e explícitos), assim como quanto ao que faz o tipo de sua institucionalização, à margem e em contestação à oficialidade sociocultural.

Convém evocar, ainda, uma pluralidade nova, que leva à perda de um consenso social mínimo. É ela quem faz aparecer no coração de nossas sociedades contemporâneas a insuficiência da privatização do religioso. Esta última foi acompanhada por acordos bastante evidentes no plano da herança cultural, das marcações do espaço e do tempo, das simbolizações e ritualidades de fundo. Ora, estas questões reaparecem hoje, num clima de diferenças mais fortes, não sem afetar o que constituía a herança, que pode se encontrar reavivada, mesmo fora da crença, graças à chegada do outro: é o caso de "valores" ou de disposições cristãs que nós podemos querer reafirmar, na Europa, frente a um Islã classificado num modelo completamente diferente, por exemplo.

Termino, enfim, pelo que denominei em outro trabalho como "religioso difuso"14, do qual não se sabe bem - e isso faz parte justamente do que deve ser interpretado - se, quanto aos contornos e às instâncias que estão em jogo, ele é ou não religioso: a valorização de "caminhos de vida" individuais, relacionados a valores não tecnocratas, funcionando mais como um modo compensatório do que representando verdadeiramente uma alternativa; uma nova busca de equilíbrio de vida, higiênico, alimentar e outros; práticas relacionadas ao paramédico; busca espiritual de tipo oriental ainda que isso não seja sem domesticação modernizadora, ou podendo ser dita ateia, como já o assinalei. As formas são distintas das dos "novos movimentos religiosos": fluidez, migração transversal a todos os tipos de pertença e de realidades sociais ocupadas em outros lugares, institucionalização fraca. Mas trata-se igualmente de produções contemporâneas, mesmo que em reação à situação anterior. E eu considero o fato como particularmente significativo: evocam-se neles mais facilmente "energias cósmicas" do que um apelo à transcendência, e vê-se neles mais facilmente o sujeito humano como se inserindo num sistema "holístico" do que chamado a um corpo a corpo com o que é, ao mesmo tempo, outro, resistente a ele e que permite um processo de vinda à existência.

Eis o que podemos dizer sobre a paisagem em matéria religiosa, para além da estrita descrição do que se expõe nela. Antes de ir mais longe, detenho-

${ }^{14}$ Qu'est-ce qu'une religion? 
me em uma citação de Slajov Zizek, marxista heterodoxo contemporâneo e psicanalista lacaniano: “Ou a religião ajuda os indivíduos a se integrarem sempre mais à ordem existente, ou ela tenta se afirmar como uma instância crítica e diz o que não vai bem nesta ordem como tal "15. A meu ver, uma parte do fenômeno religioso contemporâneo assume a primeira função. É o caso dos modos desinstitucionalizados do "religioso difuso" que citamos. E isso se encontra reanimado também no interior das tradições constituídas, inclusive nas Igrejas cristãs. Fundamentalmente, tocamos aí um religioso que assume, antes de tudo, uma função de compensação e que não é como tal provocação na cidade, nem se inscreve diretamente no campo político.

Pessoalmente, eu gosto do segundo termo da alternativa de Zizek: fundamentalmente, e tendo em vista nossa conjuntura sociocultural. O horizonte é então social, ou globalmente sociocultural. A função é, além disso, mais precisamente de contestação.

\section{b) Que leitura do passado?}

Quando se fala em religião, entende-se espontaneamente, na modernidade - particularmente na modernidade crítica -, legitimação, do político e do vínculo social: no plano dos poderes, num modo mais ou menos teocrático, de direito divino ou, na secularização, de direito natural; ou ainda, no plano das referências morais, numa fórmula atenuada, mais indireta ou com restrição do campo de pertinência e de intervenção.

Eis o que assombra nossos imaginários: o modelo de um rei em relação direta com Deus, assegurado assim de seu poder - e de um poder concebido como o encargo de um grupo. Apoiada neste imaginário, a modernidade se compreendeu classicamente como o processo de uma emancipação, que supõe, como pano de fundo, o fato ou a representação de uma "idade infantil" da humanidade, de uma servidão da qual se libertar, de um saber ainda não adquirido, de um estado de liberdade não completamente realizado. Esta mesma modernidade celebrou, em contrapartida, uma autono$\mathrm{mia}$, indo de encontro a todo regime de heteronomia - qualificada de alienação -, e afirmou uma subjetividade, ao mesmo tempo legitimada como tal e pensada como válida a partir dela mesma e por ela mesma. Num mesmo movimento, ela inaugurou uma laicidade, segundo modos diversos, uma laicidade de Estado, mas podendo ir mais longe que a estrita neutralidade do político e provocando, além disso, uma quase-laicidade do espaço público ou da sociedade civil. Em suma: uma estrita privatização do religioso.

Notemos que a rejeição da heteronomia tornou-se aqui não somente recusa da transcendência, mas de toda antecedência podendo ser constitutiva ou

${ }^{15}$ La marionnette et le nain: Le christianisme entre perversion et subversion (2003), Paris: Seuil, 2006, p. 8.

Perspectiva Teológica, Belo Horizonte, Ano 43, Número 120, p. 165-192, Mai/Ago 2011 
de toda exterioridade, ou mesmo de toda alteridade. E a afirmação da autonomia deu-se como a qualificação de um momento de começo, prometedor e criador, porque virgem, simples, natural e potencialmente universal. Uma releitura do que advém com o Iluminismo e do que adveio em seguida é eloquente; e nós sabemos hoje, na maioria das vezes, que o conjunto do que acaba de ser lembrado depende de uma construção, moderna e bastante cega: existe uma cegueira sobre si e, consequentemente, no fim, uma surpresa, ou mesmo um choque, de qualquer maneira uma pane diante do que acontece conosco hoje, no coração de nossas sociedades, em termos de violência, de afirmações identitárias, de insatisfações profundas, de nãorealizações do ideal perseguido, com seus "tiros pela culatra".

É aí que convém reconstruir as genealogias de onde viemos, a partir das surpresas presentes e das questões que nascem delas. O cenário religioso é um lugar de manifestações e de decifração disso, um lugar sintomático. Não é o único, mas ele é eloquente, talvez porque o fenômeno religioso se encontrava no centro do advento moderno, como realidade da qual se libertar e que, longe de estar simplesmente morto ou ultrapassado, é hoje perpassado por todos os tipos de redistribuições.

O trabalho a que cada um é aqui convidado - quer ele venha da teologia ou das ciências das religiões, ou ainda de outras disciplinas - é de grande fôlego e possui dimensões múltiplas. Esbocemos um ou dois pontos mais importantes deste trabalho.

Primeiramente, quanto à cegueira sobre si próprio. Sabemos hoje que o que alegamos ser natural é, na realidade, cultural, histórico e construído, logo situado. A relação com o judaísmo, ligada à famosa questão da "assimilação", o faz classicamente ver. É o caso - e aqui simplesmente como exemplos - de Rousseau e de Renan, arautos desta modernidade, dentre outros. O primeiro, na "Profissão de fé do vigário saboiano" (no coração de seu Emílio ou da educação, de $1762^{16}$ ), apresenta Jesus como herói desta "moral elevada e pura da qual somente ele deu as lições e o exemplo", precisando que "do seio do mais furioso fanatismo, a mais alta sabedoria se fez escutar, e [que] a simplicidade das mais heroicas virtudes honrou o mais vil de todos os povos". O segundo, como historiador racional, restitui e valida em Jesus o que põe sua "grande alma" acima de toda "raça", indo assim contra o Judaísmo. Por mais circunstanciais que sejam, estes exemplos parecem-me eloquentes.

Ligada a esta cegueira, nós conhecemos igualmente, hoje, a redução em ação no interior da modernidade ou sua cegueira em relação a outras organizações simbólicas, as dos "novos mundos", do extraeuropeu, do "selvagem".

${ }^{16}$ In Euvres complètes IV, Paris: Gallimard [La Pléiade], 1969, pp. 565-635, aqui p. 626.

182 Perspectiva Teológica, Belo Horizonte, Ano 43, Número 120, p. 165-192, Mai/Ago 2011 
Nesta matéria, a modernidade foi ou se quis progressista: da religião à metafísica, depois à ciência; e, internamente ao religioso: do animismo ao politeísmo, depois ao monoteísmo que prepara a racionalidade da metafísica e, para além dela, da ciência positiva. Justamente sobre este eixo, existem hoje um "retorno" e uma outra validação, assim como, em cada um, um interesse pelo étnico e também por outras civilizações.

Segundo ponto: retomar em que ponto estamos em matéria de transcendência, de seu estatuto e de sua relação ao mundo, autointitulada de legitimação direta, a reconhecer ou a rejeitar; uma história de longa duração pode somente mover aqui o terreno de cristalização e seus jogos de alternativas, num face a face não sem reviravoltas.

No eixo da relação à transcendência - de sua articulação ao mundo e à cidade, com as questões do sujeito e da história ligadas a ele - coloca-se em evidência uma história interna ao Ocidente mais diversificada do que acredita uma modernidade que, tanto em suas afirmações reativas (reacionárias) como em suas afirmações inovadoras (emancipadoras), é facilmente caricatural. E é uma diversidade que, revista, pode conduzir à instalação de uma ordem de problemas.

Assim, em relação à transcendência ou a Deus, pode-se notar uma oscilação - em partes, uma passagem - entre, de um lado, a afirmação antigo-medieval de uma transcendência fora do mundo, articulada a uma "economia", a uma história e ao político desincronizados, em assimetria e heterogeneidade recíproca - donde o "an-árquico"17 inscrito no princípio e uma ratificação dada à consistência do mundo e do que nele se passa -, e, do outro lado, uma visão própria aos Tempos Modernos, nos quais "providência geral" e "providência especial" tendem a coincidir, e a transcendência tende a valer como fundamento direto do "econômico", da história e do político.

Em relação ao sujeito, pode-se notar igualmente uma oscilação entre, de um lado, a passagem de um sujeito em posição central ao primeiro plano (lugar de um trabalho do Espírito, em relação com nada menos que Deus), sem privá-lo, entretanto, no momento antigo-medieval, de uma relação de distância face a um cosmos que o ultrapassa e vale a este título (é o lugar da "virtude de religião", herdada de Cícero e separada da virtude da "fé", única "teologal"), num horizonte mais de sabedoria que de saber, e, do outro lado, uma reivindicação cada vez mais direta e imediata, dominada por um chamado - de matriz profética - ao princípio de uma vocação de inscrição no coração do mundo.

\footnotetext{
${ }_{17}$ Para este vocabulário, cf. G. AGAMBEN, Le règne et la gloire: Homo sacer, II, 2 (2007), Paris: Seuil, 2008, pp. 99-101 (e cf. pp. 94s.), 108s., 214s., 318.
} 
Em relação à história, enfim, pode-se notar ainda uma oscilação: na Antiguidade cristã, notar-se-á uma passagem da história ao primeiro plano, como lugar de inscrição da verdade, mas trata-se de uma história fundamentalmente diferenciada e não homogeneizada, marcada por um antes diferente e que deve ser "relembrado" -, e por um depois, diferente e objeto de uma virtude de "esperança", uma história na qual a verdade não se dá jamais diretamente - nem de fato, nem de direito -, mas é trabalhada por uma dialética fundamental: a dialética das duas cidades de Santo Agostinho fornece aqui um exemplo eloquente e decisivo. Na época moderna domina frequentemente, ao contrário, a linha de uma "história da salvação" que tende a se tornar única e assimiladora, o escatológico ou o messiânico figurando seu termo final.

As diferenciações que são evidenciadas por uma perspectiva genealógica da temática da transcendência ultrapassam o segmento do destino ocidental que nós herdamos e se encontram se o ângulo de visão se amplia. É o caso de cidades gregas - particulares e atravessadas por debates internos e por outras regulações - ou de sociedades tradicionais estudadas pelos antropólogos. Nestes lugares, os chefes têm seu poder limitado - temporalmente também - ou são submetidos a diversos ritmos ou alternâncias. Estas sociedades são "sem Estado", cujo modo é fundamentalmente homogeneizante, reduzindo os deuses, os ancestrais ou outras forças cósmicas que dão um ritmo à relação ao mundo, à natureza ou ao extra-humano.

Se o modelo de um rei em relação direta com Deus - assegurado assim de um poder de coesão ou de unificação - não é o modelo das sociedades ditas tradicionais, ele é o modelo do Egito, inscrito em nossa memória coletiva ${ }^{18}$. Ora, em nossa memória, devemos ou nos distinguir dele, no modo de uma irredutível singularidade - é o caso do judaísmo e de seus herdeiros ${ }^{19}$, mas é uma via um pouco esquecida ou desconhecida -, ou derrubá-lo, e é o que acontece frequentemente na modernidade, podendo mesmo iniciar uma revisão diferida - mas do mesmo tipo -, não sem a recorrência de um motivo utópico - no qual nada é exterioridade irredutível e potencialmente constitutiva, mas tudo é submetido à razão organizadora. A leitura de Thomas Morus é aqui eloquente - e mesmo amedrontadora.

Notemos que o Egito cristaliza aqui um tipo específico, mesmo sem recapitular o que foram os Impérios antigos, com - como modelos de referência a Pérsia, em seguida os períodos helenístico e romano, que conheciam

${ }^{18}$ Cf. J. ASSMANN, Moïse l'Egyptien: Un essai d'histoire de la mémoire (1997 e 1998), Paris: Aubier, 2001.

${ }^{19}$ Podemos estimar que o judaísmo cristalize uma particularidade de separação sob um fundo de transcendência externa, e que a dialética agostiniana das duas cidades reproduza a separação, sob um fundo universal, segundo a vontade da problemática específica de um crer transversal, em relação a um Deus Outro. 
diferenciações, ausência de imediatez e de relações diretas. Se existia uma hierarquização - entre o "Grande Rei" e os diferentes reinados e principados do Império ${ }^{20}$-, era mais segundo mediações organizadas que sob um modo totalitário avant la lettre, ainda que, evidentemente, isso não excluísse a violência.

Além disso, mesmo na tradição da qual nós viemos majoritariamente, marcada por um monoteísmo com uma história complexa, existe uma diversidade de instâncias em termos de autoridade e de poder, fora da homogeneização e mesmo fora da subordinação estrita. Nós poderemos notar que, no Antigo Testamento ou na Bíblia judaica, não existe um reinado - um reinado nem originário nem constitutivo - sem polaridade com um polo profético e, consequentemente, nada de reinado sem a atuação de um jogo de contestações em princípio normais e necessárias (sem contar o poder dos sacerdotes...). Quanto ao cristianismo histórico, ele não conhece a figura de um sultão que deve conjugar poder religioso e poder político: existe em princípio uma dualidade entre o Papa e o Imperador, ainda que, de fato, tenha havido frequentemente concorrência e contestações num mesmo terreno, e ainda que existam Estados Pontifícios e, na modernidade, uma extensão das prerrogativas reivindicadas pela Igreja com, consequentemente, uma modificação em profundidade da concepção do que pode fazer sua própria instância, assim que uma modificação - articulada - da compreensão do político.

\section{c) Em que situação nos encontramos ao termo de uma história de emancipação?}

Após as releituras históricas, mais diferenciadas do que as que recebemos espontaneamente, passemos a uma consideração crítica dos efeitos reais da emancipação. Digamo-lo sem demora, a situação de nossas sociedades contemporâneas é caracterizada por uma negação de tudo o que é excede o ser humano, "mestre e possuidor", e por uma secreta homogeneização ${ }^{21}$. Uma assimilação que reduz as diferenças, mas que deixa assim "retornar" o que lhe subjaz de não-integrável - como um retorno do recalcado -, num modo dito irracional e selvagem. Uma parte do que se passa no cenário religioso contemporâneo põe-no em evidência.

No plano de nossa sociedade global - o viver juntos e cada um dos indivíduos -, deve-se notar uma série de disfunções. Em desordem e cada uma

\footnotetext{
${ }^{20}$ Cf. a este propósito E. PETERSON, "Le monothéisme: un problème politique" (1935), in ID., Le monothéisme: un problème politique, Paris: Bayard, 2007, pp. 45125.

${ }^{21}$ Sobre este assunto, cf. P. GISEL / I. ULLERN (org.), Le déni de l'excès: Homogénéisation sociale et oubli des personnes, Paris: Hermann, 2011.
} 
devendo ser afinada, diferenciada, problematizada: fenômenos ditos "regressivos", surpreendentes aos olhos da racionalidade estabelecida, desde então considerados "irracionais" ou "arcaicos" (podendo se dar não sem violência segundo os casos), e vistos como defeitos de assimilação, aos quais se deve remediar por uma evidente redução das diferenças, ao passo que eles anunciam uma resistência; uma tendência homogeneizante global; uma exclusão interna, relacionada à inadaptação de ordens diversas; um desastre ecológico; um desmoronamento das mediações operantes, ligado a uma explosão em puras individualidades ou a uma simples justaposição; uma multiplicação infinita de diretivas administrativas e técnicas; uma fuga perpetuamente projetada para o futuro; uma pane em termos de visão global e de projeto, consequentemente de responsabilidade (inclusive o famoso "cansaço de ser si mesmo"), também de uma possível simbolização (logo, de relação ao espaço, ao tempo, ao outro, com consequentemente, uma crise de identidade), ligada à transformação de tudo em gadgets ou à construção de celebridades (a "sociedade do espetáculo").

Contrariamente à representação que se faz a modernidade, oficial ou difusamente, a história não é jamais linear: os diversos "retornos" indicam justamente isso. Existem descontinuidades quanto às diversas maneiras de dispor o indivíduo, o social, as instâncias que o atravessam, podendo ou não se institucionalizar.

Logo, nada de linearidade, mas "retorno" - fala-se neste caso do "recalcado", que "faz um retorno" justamente. Num sentido freudiano: o retorno diz respeito ao efeito, diferido e diferente. Isso não quer dizer que um dado fundamental - religioso ou outro - tenha sido objeto de recalque e que, simplesmente, ele retorne. Nada "retorna", em termos de dado, mas existe um sintoma que - no cenário religioso, entre outros cenários ${ }^{22}$ - diz indiretamente, para falar como Zizek, "o que não vai bem", com a sociedade como tal ou em seu coração.

Eu remeteria, de bom grado, a uma corrente de pensamento que passou pela Escola de Frankfurt, período de uma forte consideração do religioso - fora das confissões engajadas e fora das ciências das religiões. Ela dá alguns diagnósticos virulentos sobre o próprio lugar da afirmação moderna, cada um em seus acentos e perspectivas próprias: Slajov Zizek, evidentemente, mas também Peter Sloterdijk ${ }^{23}$ ou Giorgio Agamben. Em matéria de

22 O cenário econômico, o cenário dos futuros institucionais ou o cenário das artes podem também pôr em evidência realidades antropológicas e sociais mais amplas, cada vez sob um ângulo próprio: uma maneira específica de ver, ou uma outra maneira de ver, mesmo que cada um possa enriquecer - complexificar para começar - o que globalmente se mostra, ainda que cada um deva provavelmente, a seu modo e em seu campo próprio de visão, integrar uma parte desta complexidade.

${ }^{23}$ Cf. La mobilisation infinie [original: Eurotaoismus, 1989], Paris: Bourgois, 2000;

La folie de Dieu: Du combat des trois monothéismes (2007), Paris: Libella-Maren Sell, 
constatação, remetendo à história da qual viemos, citarei mais uma vez Zizek, que sustenta que o resultado final da subjetivização moderna e humanista é "o desaparecimento de nossa própria subjetividade, sua transformação em capricho derrisório", ou, não sem paralelo com o Nietzsche da produção dos "últimos homens", estes "indivíduos pós-modernos que rejeitam todos os objetivos 'superiores' como terroristas e que consagram sua vida a uma sobrevida cheia de pequenos prazeres cada vez mais refinados e excitados/despertados artificialmente" 24 .

\section{d) Uma questão a revisar: o que se pode dizer do par transcendência e subjetividade?}

Em defasagem com a modernidade evocada, passamos por Nietzsche, sua crítica do antropocentrismo moderno e da aniquilação da polifonia do mundo; com seu destaque contrastante de uma fidelidade à terra, de um deus dançante, múltiplo, não redutível ao humano. Analogicamente, evocar-se-á a revalorização de um "gênio do paganismo" (Marc Augé) ou de disposições antigas, ricas de virtudes posteriormente recalcadas (Jean-Pierre Vernant, Marcel Detienne).

Como releitura do processo moderno e como diagnóstico sobre o mundo contemporâneo, a temática que deve ser retrabalhada gira em torno do par transcendência e subjetividade. Os dois termos se sustentam, ao mesmo tempo, historicamente no centro dos processos em jogo e, a meu ver, secretamente no centro das dificuldades ou das aporias do mundo contemporâneo.

Na modernidade clássica, crítica em relação ao religioso dominante - de forma cristã -, os dois termos foram experimentados como antitéticos, constituindo uma alternativa - na qual honrar um dos polos significava desvalorizar o outro, e reciprocamente (clássico na matéria: Feuerbach). Hoje, pressente-se que existe um problema em cada um dos dois polos e que se deve interrogar sua conexão - o par formado de fato por eles, inclusive numa história de memória e de imaginário - e retrabalhar o que significa e o que pode significar, agora, cada um dos dois termos.

Como primeira observação, lembremos que o polo da transcendência deu uma forma - específica, sublinham as ciências das religiões contemporâneas; logo tudo, menos universal, mas que deve então ser interrogada como específica - ao que mais amplamente é, para o humano, em excesso: a alteridade, ameaçadora e promissora, o que se sustenta nas fronteiras e deve

2008; Colère et temps (2006), Paris: Libella-Maren Sell, 2007; Tu dois changer ta vie: De l'anthropotechnique (2009), Paris: Libella-Maren Sell, 2011.

${ }^{24}$ La marionnette et le nain, pp. 55s. 
ser afastado, marcado, assinalado, simbolizado, ritualizado. Convém imediatamente acrescentar que, especialmente na história moderna - inclusive da teologia -, este polo da transcendência deu forma ao excesso esconjurandoo; concretamente: construindo um "onto-teológico" integrador, no qual a transcendência é ao mesmo tempo o fundamento, primeiro e último, do que existe e ratificação dada a tudo o que existe.

Notemos que isso é uma disposição moderna e que se marca aí uma descontinuidade tanto em relação à transcendência em forma do Uno além do ser do neoplatonismo (dominante, ainda que com corretivos, durante toda a Idade Média cristã, e evidentemente já na Antiguidade cristã) quanto à temática central de uma disproportio, irredutível, entre o que compete a Deus e o que compete ao mundo, este último sendo ratificado através da autonomia das "causas segundas" que o constituem.

O recurso à transcendência de disposição moderna e a maneira de fazê-la funcionar darão lugar aos programas políticos supostos pelo Syllabus romano de 1864, "catálogo de erros" deste tempo, ou às teorias contemporâneas do meio "evangélico", de um Dominion afirmando um senhorio global, devendo ser direta! - de Jesus ou de Cristo (nós conhecemos as intrusões no campo diretamente político nos Estados Unidos). Também aí há uma disposição moderna - de tipo reacionário -, em descontinuidade com a visão clássica da "cidade de Deus" e da "cidade terrestre", necessariamente entrelaçadas e não separáveis, nem de fato nem de direito. Além destas posições de tipo absolutista, a modernidade deu lugar também a inversões: secularizações, no sentido schmittiano. Postas face a face, quase constitutivamente e sem tertium datur. Fantasia-se sobre o antes - nos dois campos - e, consequentemente, do lado desde então dito laico, cristaliza-se primeiramente uma rejeição - compreensível - da transcendência, mas que se torna, ao mesmo tempo, rejeição de tudo o que subentendia seu propósito, concretamente: rejeição do que excede o humano.

Numa segunda observação, convém registrar que o recurso à transcendência deu forma à simbolização, através de uma "grande narrativa" assegurando uma visão geral do humano, uma relação ao espaço e ao tempo, permitindo que uma identidade se cristalize. Aqui igualmente, a rejeição de transcendência deixou um espaço seja à substituição, de disposição semelhante - ao extremo, o marxismo -, seja a um vazio, a "vida nua", desde então entregue aos "bio-poderes".

Repitamo-lo, a forma e o estatuto dados ao que de fato responde tanto pelo que excede o humano quanto por uma necessária simbolização - no caso, o recurso a uma transcendência - não constituem, primeiramente, a única disposição possível: as maneiras que o humano possui para se desdobrar e "negociar" com o mundo e com o que o ultrapassa são múltiplas, tanto diacrônica (ver a Antiguidade clássica) quanto sincronicamente (ver o 
extraeuropeu). Entretanto, isso não significa que não se deva trabalhar. Esta disposição tem, além disso, uma história - mais diferenciada do que imaginamos espontaneamente: existem várias maneiras de dispor o próprio tema de uma transcendência e muitas maneiras de fazer uso dela, inclusive em termos de crítica, crítica interna às vias religiosas que reenviam a ela, ou crítica dos sistemas naturais e sociais habitados pelo humano, ou das maneiras que ele tem para se instalar nela.

\section{e) Qual orientação possível quanto ao que nos é pedido?}

Convém, primeiramente - o leitor terá compreendido -, ir além das alternativas rígidas e caricaturais que ocupam nossos imaginários e dirigem nossos reflexos espontâneos. E ir além, é claro, tanto da questão de um simples "retorno" à situação anterior (seja ele temido ou celebrado) quanto de um novo "modelo" a ser instaurado. Ao contrário, assumiremos firmemente as questões de hoje, em sua sincronia própria ou o sistema integral aos quais elas tocam, mesmo se isso pode exigir um desvio - pela história e por uma genealogia dos problemas.

Globalmente, a partir do que se evidencia no cenário religioso, convém repensar a série: indivíduo, sociedade civil, política, fato religioso. Isso ratificará a modernidade - são seus modos que devem ser repensados -, ao mesmo tempo, quanto a uma necessária diferenciação das instâncias de regulação social e dos tipos de discurso, à pertinência, aos limites de validez e à argumentação cada vez específicos, e ao mesmo tempo quanto ao polo próprio que representa aí - em posição central, mas não isolada - o indivíduo.

No tocante à política, deve-se pensar e assegurar o Estado, mas um Estado antes de tudo árbitro, reduzido então quanto à pretensão que pode ser a sua na modernidade (a secularização de um modelo que aqui problematizamos). Isso supõe reelaborar a questão de sua função, de seu estatuto, de suas finalidades.

O civil deve ser reavaliado. Ratificado como mais diversificado do que pensou e quis uma modernidade dominadora (a "vontade geral" dos revolucionários franceses ou o "homem genérico" da esquerda hegeliana, dando nascimento à "sociedade sem classe", todas temáticas herdadas também de um período que deve ser problematizado), de uma diversidade de fato, que deve ser considerada e pensada como sendo de direito. Aí está o primeiro lugar de existência e de desenvolvimento do indivíduo, e o caráter irredutível das diferenças que o atravessam - religiosas, para começar, mas outras também - pode somente relançá-lo em seu advento próprio, singular (o civil será, além disso, visto como o lugar do religioso e de suas organizações). 
Eu posso, pessoalmente, ratificar que se fale de um reconhecimento de comunidades religiosas como sendo de interesse público. Apesar das dificuldades de sua gestão: o que é uma comunidade "religiosa", o que pode significar seu interesse "público", e em que base "reconhecer"? Esta temática não elimina a questão da tolerância, que é diferente, devendo ser assegurada de outra parte pelo Estado, sem reserva, salvo polícia e defesa dos fracos. Um reconhecimento supõe um modo de tipo contratual (ninguém é obrigado a isso: o reconhecimento deve ser pedido), no qual o Estado reconhece uma contribuição benéfica à sociedade (como se diz em relação ao esporte e à cultura), através de um quadro e de condições aprovadas (um Estado de direito para começar ${ }^{25}$. Isso obriga o Estado a não se pensar como fonte $e$ mestre de tudo, consequentemente a precisar seu estatuto; e o que, reciprocamente, obriga, mesmo indiretamente, as comunidades religiosas concernidas a um trabalho interno sobre sua relação ao civil e ao que elas não são, e aqui de direito - o que as obriga em paralelo a repensar o que significa, para elas, o religioso -, sem contar que o conjunto é tecido num clima de diferenças de tradições, de referências ou de maneiras de considerar o humano no mundo.

Após o político e o civil, vejamos o indivíduo - polo próprio, central e irredutível em sua singularidade mesma. Como ser humano - e aqui, como responder por si -, e como permiti-lo do melhor modo - o político se preocupará com isso, sem mais -, não passa por uma situação religiosa "essencial", mas seguramente por dimensões múltiplas e por traços misturados, feitos de heterogêneo, que tem ou tiveram suas formas religiosas é o caso, por exemplo, de uma marca "messiânica" que vários herdeiros da Escola de Frankfurt tentam validar ligada a uma maneira de viver o presente.

Neste conjunto, eu não poderia simplesmente ratificar a secularização "essência da modernidade", diz Gianni Vattimo e, para ele, transferência da "essência do cristianismo", iniciando uma política da "amizade" fora da "heteronomia". O homem é, de fato, mais complexo, e isso explode hoje em toda parte. E ele o é de direito. O religioso o sustentou e o sustenta, às vezes para seu azar, mas pleno também de uma busca e de uma força que deve ser retomada, repensada, transposta ou da qual se deve permitir o desdobramento, para o proveito do ser humano como tal e de sua vida secular.

\footnotetext{
${ }^{25} \mathrm{Eu}$ não escondo a dificuldade ligada ao fato de que o religioso pode legitimamente dizer uma realidade outra e não submissa ao político - a Igreja confessante sob o nazismo deu uma instrução sobre isso para sempre instrutiva; mas ela teve que se integrar, para se validar na perspectiva que eu indico aqui, por uma teoria do político como tal e na argumentação pública, não denunciar então o nazismo como uma política má, mas como um desvio ou uma perversão da própria política, o que deve ser validado e argumentado justamente como tal.
} 
O leitor terá compreendido que, para além das atuações históricas esboçadas ou segundo sua vontade, isso passa por uma retomada do que significa a institucionalização (as sociedades morrem e, sobretudo, o ser humano, quando tudo não passa de um funcionamento técnico e pura adaptação), o que assegura a mediação (a humanidade não é feita somente de indivíduos justapostos, que existem por sua pura espontaneidade de vida), o que se relata do ser humano: dizer, em ocorrência, uma história da relação à alteridade, interna e externa. Será uma história como lugar de um enigma do humano (não se considerará a "fábula" como verdadeira em si mesma), uma história particular (o homem é sempre particular), mas que saiba de que ela é feita e $o$ que ela pode valer, num contexto universal que vai além dela. Resumindo: que saiba dizer - e primeiramente para si mesma - em que ela é aqui uma encarnação - uma entre outras - do humano.

Assistimos hoje ao retorno de um não-integrado - humano - no centro das secularizações: e o cenário religioso, entre outros cenários, coloca-o em evidência. Um não-integrado que assinala um não-integrável, sempre humano ("o que torna a vida digna de ser vivida, é o excesso da própria vida", escreve Zizek $\left.{ }^{26}\right)$.

Ora, a modernidade tem uma propensão quase nativa à homogeneização, a negar o que é, para o humano, o excesso, o que vai além dele ou é irredutível a sua razão espontânea (universal?), como as intransponíveis e amplas diferenças que fazem o humano ou através das quais o humano se $f a z^{27}$. A teologia sustentava isso, mas ela tende a esquecer - ou a esquecer em que ponto isso ia além de suas afirmações próprias, enquanto estas afirmações viviam isso - e a se fechar em sua comunidade a partir de um específico que a fundaria. Quanto às ciências das religiões, elas não se preocupam verdadeiramente, na maioria das vezes, em falar do que se sustenta aqui em ação, nem querem dizer o que é afetado por isso num presente dado, nem o porquê - elas querem ainda menos esboçar em que ponto há aqui, sempre em relação a este presente, aporias e oportunidades - escolhendo permanecer na descrição, mesmo podendo deixar estas questões a outros: às subjetividades - comunitárias ou individuais - sem regulação social e sem orientação, porque fora da objetivação do que faz o cenário real.

É em torno a este tipo de questões que, de fato, o que é subjacente ao exercício usual da teologia e o que é subjacente ao trabalho corrente das ciências das religiões podem - devem? - se reunir, sem perder, entretanto, o que faz suas diferenças, que têm sentido e legitimidades - históricas e de

\footnotetext{
${ }^{26}$ La marionnette et le nain, p. 122.

${ }^{27}$ Ela está, consequentemente, em pane de simbolização.
} 
fundo -, mas se transformando, todavia, ou integrando mudanças, segundo o que é necessário, sempre a partir de suas próprias perspectivas.

(Tradução do original francês por Francys Silvestrini Adão SJ)

Pierre Gisel, nascido em Genebra (Suíça), é doutor em teologia pela Faculdade de Teologia da Universidade de Genebra, tendo defendido a tese intitulada "História e verdade em conflito. Ernst Käsemann" (1975), e doutor honoris causa pela Universidade de Sherbrooke (Canadá, 2011). Atualmente é professor e decano da Faculdade de Teologia e de Ciências das Religiões da Universidade de Lausanne (Suíça). Destacam-se algumas de suas obras: Vérité et histoire, Paris: Beauchesne, 1977 ( $2^{\mathrm{a}}$ ed. 1983); La Création, Genève: Labor et Fides, 1980 (2 ed. 1987); Le Christ de Calvin, Paris: Desclée, 1990 ( $2^{\mathrm{a}}$ ed. 2009); L'excès du croire: Expérience du monde et accès à soi, Paris: DDB, 1990; La Subversion de l'Esprit, Genève: Labor et Fides, 1993; Sacrements et ritualité en christianisme, Genève: Labor et Fides, 2004; Les monothéismes: Judaïsme, christianisme, islam, Genève: Labor et Fides, 2006; Qu'estce qu'une religion?, Paris: Vrin, 2007; La théologie, Paris: PUF, 2007; Traiter du religieux à l'Université: Une dispute socialement révélatrice, Lausanne: Antipodes, 2011; P. GISEL / L. KAENNEL (org.), Encyclopédie du protestantisme, Paris / Genève: PUF / Labor et Fides, 2006, $2^{\mathrm{a}}$ ed.

Endereço: Chemin de la Tour-Grise $\mathrm{CH}-1007$ Lausanne e-mail: Pierre-Gisel@unil.ch 